\title{
The optimization and economic evaluation of oil production using low salinity polymer flood: a case study for EOR 26
}

\author{
Marvin Flatts ${ }^{1} \cdot$ David Alexander $^{2} \cdot$ Rean Maharaj $^{3}$
}

Received: 3 June 2021 / Accepted: 27 November 2021 / Published online: 10 December 2021

(c) The Author(s) 2021

\begin{abstract}
Trinidad and Tobago (TT) have been producing crude oil commercially since 1908. For the past few decades, TT's crude oil production has been in steady decline because most of the oil reservoirs are beyond the primary phase of their production. This situation coupled with lower energy prices have resulted in a shortfall in TT's energy revenues and presents TT with major economic challenges. The objective of this study was to optimize a field simulation model of a combined Low Salinity Polymer Gel flood to highlight the possibility that Enhanced Oil Recovery (EOR) can boost crude oil production especially from heavy oil reserves and mature fields. A field simulation model of the EOR 26 Upper Forest Sands was built using the CMG Builder software. The EOR 26 Upper Forest Sand reservoirs of the Forest Reserve field are delineated by shale-outs, faults and water-oil contacts. The entire Forest Reserve is bordered by the Fyzabad anticline to its north-west and the Los Bajos fault to its south-west. A dynamic field simulation model of the combined Low Salinity Polymer Gel flooding of EOR 26 Upper Forest Sands was created using CMG STARS software and the optimum parameters of polymer gel concentration, salinity concentration and injection rates and pressure for the highest oil recovery were investigated. The highest oil recovery was obtained using a polymer gel concentration of $500 \mathrm{ppm}$ with a salinity of $1000 \mathrm{ppm}$ and an injection rate of $900 \mathrm{bbls} /$ day during continuous polymer gel injection for a period of 545 days. The polymer gel injection was preceded by pre flush water injection for 180 days and followed by water injection for the duration of the ten (10) year period. The predicted oil recovery for the project is an additional $14.52 \%$ of OOIP and is considered economically feasible at a crude oil price of US\$50 per barrel with a payback period of two years and an IRR of $63.53 \%$.
\end{abstract}

Keywords Enhanced oil recovery $\cdot$ Polymer flood $\cdot$ Low salinity $\cdot$ Simulation $\cdot$ Field optimization

\section{Introduction}

TT is situated at the end of the Caribbean archipelago and according to the Worldometer has oil reserves at 728,300,000 barrels as of 2016 (https://www.worldomete rs.info/). As shown in Fig. 1, the production trends are generally declining from a maximum output of approximately 243 Mbbls per day in the year 1981-58 Mbbls per day in 2018. TT's crude oil production decline is associated with factors

Rean Maharaj

rean.maharaj@utt.edu.tt

1 Energy Systems Engineering Unit, The University of Trinidad and Tobago, Point Lisas, Trinidad and Tobago

2 Energy Systems Engineering Unit, The University of Trinidad and Tobago, Point Lisas, Trinidad and Tobago

3 Process Engineering Unit, The University of Trinidad and Tobago, Point Lisas, Trinidad and Tobago such as a reduction in exploration activity during the 1990s and early 2000s and the lack of capital investment to fund work overs and drilling activities, which could have resulted in an increased crude oil production. The decline in crude oil production has also highlighted the absence of a comprehensive plan to manage the country's energy resources to ensure that there is sustainable development throughout the upstream sector. EOR methods present the opportunity to mitigate the negative trend in production in the short to medium term.

TT has a long history with EOR/IOR projects with some success as outlined by Sinanan, Evans and Budri (2016). According to data from the Ministry of Energy and Energy Industries (2019), during the period 2003 to 2004, EOR/IOR projects accounted for 8.8 percent of total crude oil production. Sinanan, Evans and Budri (2016) suggested that with proper planning and investment, EOR/IOR projects could contribute at least 15 percent to the total crude oil production 


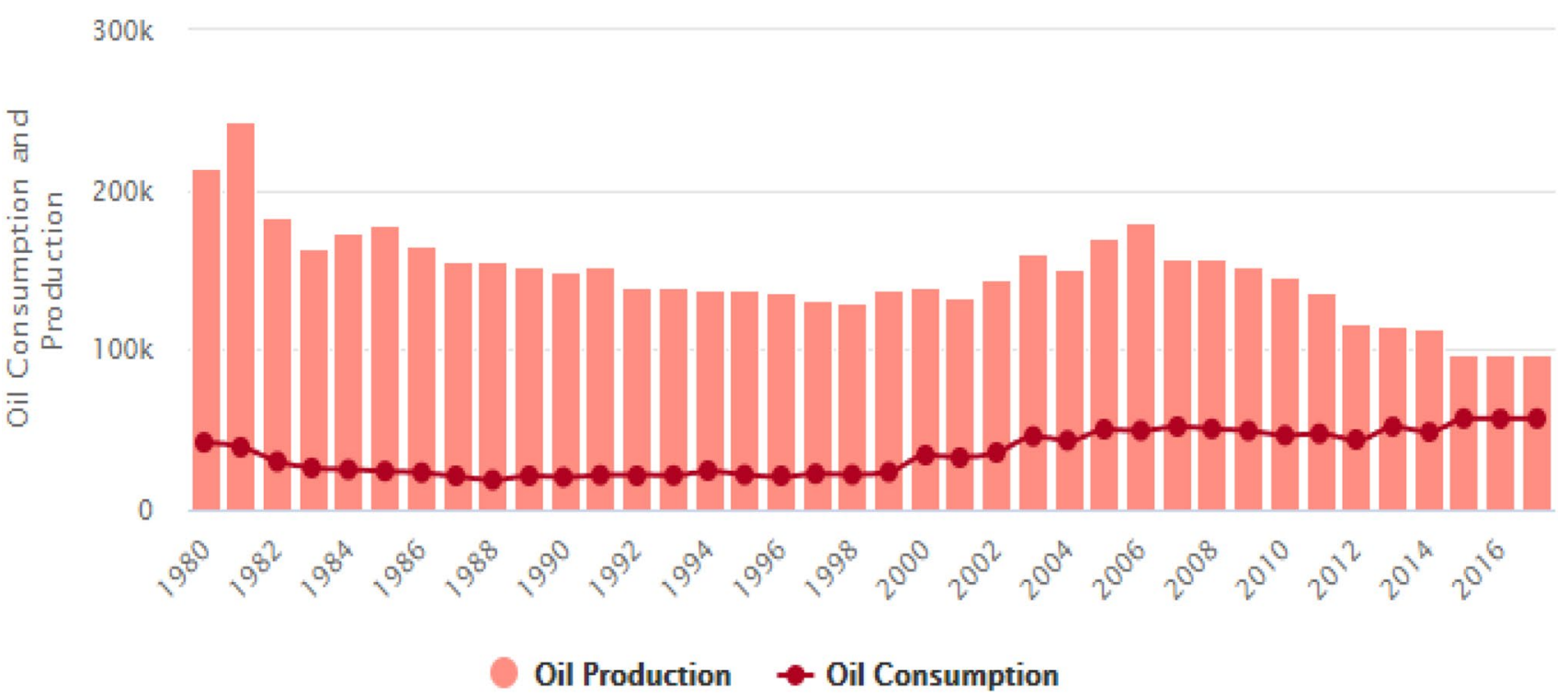

Fig. 1 Crude oil production and consumption (barrels per day) in Trinidad and Tobago by year from 1980 to 2018 (https://www.worldometers. info/oil/trinidad-and-tobago-oil/)

in the future. One of the main EOR/IOR strategies adopted in TT has been waterflooding while there has been only two chemical polymer-based EOR projects implemented thus far. Based on improved technologies in the area, TT can benefit from an investment in and implementation of chemical EOR methods especially polymer-based flooding strategies. Work done by Thomas (2006) showed that worldwide crude oil production due to chemical EOR/IOR projects was approximately $300000 \mathrm{bbl} / \mathrm{d}$ with over $80 \%$ of that figure being attributed to polymer-based projects in China. As reported by Delamaide et al. (2014), there were significant increases in crude oil production and oil recovery due to polymerbased EOR/IOR projects in Canadian heavy oil reservoirs. The success of the polymer-based EOR/IOR projects in Canada is relevant to TT as it demonstrates the potential to produce oil from their extensive heavy oil reserves as well as from abandoned waterflooding projects due to excessively high water cuts.

The mechanisms of action for the polymer-based flooding technology is well documented and basically involves increasing the viscosity of the water (the displacing fluid) used in water flooding to increase its sweep by reducing the mobility ratio of the water (Luo et al. 2006; Yin et al. 2006 and Xia et al. 2008; Wang et al. 2009). Polymer flooding techniques include Alkaline Surfactant Polymer (ASP) flood (Sheng 2013), Alkaline Polymer flood (Fortenberry et al. 2015), and Low Salinity Polymer flood (Mahani et al. 2015). The types of polymer utilized in the application of polymer flooding can be either biopolymers or synthetic polymers. Biopolymers are derived from a fermentation process rather than by direct synthesis from their monomers in a chemical reactor, whereas synthetic polymers are synthesized and their performance in a polymer-based flooding situation is based on their molecular weight and their degree of hydrolysis (Needham and Doe 1987). According to Needham and Doe (1987), biopolymers have relatively low adsorption to formation rock, relatively high resistance to shear degradation and excellent viscosifying power in high salinity waters. Biopolymers can be relatively expensive when compared to synthetic polymers. Synthetic polymers are relatively cheap; exhibit excellent viscosifying power in fresh water and their adsorption on rock surfaces produce a long lasting reduction in permeability (residual resistance effect). Synthetic polymers have a tendency to shear degradation at high flow rates and exhibit poor performance in high salinity waters.

Several critical factors can affect the performance of a polymer flooding chemical agent. The concentration of the polymer used as well as its molecular weight are critical parameters. According to Sheng (2013) and Sheng (2015), as the molecular weight increases, the concentration required to achieve the desired viscosity of the polymer-based solution decreases. The general relationship whereas the concentration of the polymer in solution increases, the viscosity of the polymer solution increases holds (Ramkissoon et al. 2021). The consideration of the viscosity factor is dual in nature as it involves the impact of the oil viscosity itself when evaluating the formation fluids as well as the influence of the viscosity of the chemical polymer-based flooding agent on the mobility ratio of the displacing fluid. Sheng (2013) and Sheng (2015) suggested that generally polymerbased flooding is most effective in reservoirs with formation fluids possessing viscosities of less than $150 \mathrm{cp}$. The 
understanding and application of the use of $\mathrm{pH}$ is also pivotal to the success of any chemical EOR method especially polymer-based flooding as it can affect reservoir rock wettability and polymer viscosity (Ramkissoon et al. 2021; AlAnazi and Sharma 2002). Studies including work by Lager et al. (2008), Morrow and Buckley (2011) and Mahani et al. (2015) have all highlighted the effects of salinity especially the advantage of low salinity water injection. Their research has shown that low salinity affects the rock wettability as the reservoir rock containing residual oil will transition from a more oil wet to more water wet in the presence of low salinity. A study done by Ramkissoon et al. (2021) demonstrated that for the biopolymer Xanthan Gum, as salinity increases, the apparent viscosity of the biopolymer decreases and the adsorption of the biopolymer on rock surfaces increases. Permeability is an important reservoir characteristic for flow and fluid propagation. In polymer-based flooding, the relative permeability of the displacing fluid $\left(\mathrm{K}_{\mathrm{rw}}\right)$ is reduced to a value lower than the relative permeability of the oil flow $\left(\mathrm{K}_{\mathrm{ro}}\right)$ through disproportionate permeability reduction and it is one of the many mechanism working in the subsurface that results in the improved sweep efficiency of polymer-based flooding (Sheng 2015). Apart from the general characteristics of chemical flooding agents, polymer injection characteristics are also very important. The injection characteristics of importance include the formation fracture pressure for the selected reservoir, the polymer concentration required to achieve the desired viscosity downhole, the polymer injection rate necessary to reduce or minimize shear degradation and the injection pressure to ensure propagation of the polymer slug without fracturing the reservoir formation. Research by De Simoni and workers (2018) and Al-Shakry et al. (2018) showed that formation fractures near the wellbore had beneficial effects in maintaining satisfactory well injectivity when injecting a viscous fluid.

The use of chemical EOR methods specifically polymerbased techniques have been recently studied in TT. As summarized by Ramkissoon et al. (2021) studies focussed on the interrelationship between polymer adsorption, viscosity, $\mathrm{pH}$ and salinity towards the application of low salinity polymerbased flooding using the biopolymer Xanthan Gum. Work done by Alghazal and Ertekin (2018) and Dukeran et al. (2018) formulated the optimum polymer concentrations required for different polymers for suitable reservoirs in TT.

The objective of this study is to utilize the findings of previous studies conducted to optimize a field simulation model of a combined Low Salinity Polymer Gel flood using the CMG Builder software. The EOR 26 Upper Forest Sand reservoirs of the Forest Reserve field was selected to conduct the field simulation model in an attempt to highlight the possibility that EOR can boost crude oil production especially from heavy oil reserves and mature fields. The optimization of variables considered in this study was simultaneous since more than one variable will be used to improve the total oil recovery of the EOR 26 Upper Forest Sands reservoir.

\section{Methodology}

\section{Field selection}

The selection of the Upper Forest Sands field for the purpose of this study was based on the criteria utilized for the consideration of chemical EOR methods as outlined by Taber et al. (1997) and Saleh et al. (2014). The EOR 26 Upper Forest Sands Reservoir Rock Properties shown in Table 1 satisfied the selection criteria guide for polymer flooding according to Saleh et al. (2014) shown in Table 2.

\section{Simulation models}

The simulation models were created using the commercial software Computer Modelling Group Limited software (CMG-STARS). Using the CMG Builder software, the base model was developed using a digitized version of the structure contour map of the Upper Forest Sands along with information from the gamma ray log for the field and other reservoir parameters that were obtained from research conducted by Mohammad-Singh et al. (2004). The reservoir is a three dimensional dual permeability, dual porosity, non-orthogonal corner point model developed using a digital structure contour map of EOR 26 Upper Forest Sands. In all the reservoir simulation models constructed, the reservoir was heterogeneous with thirteen layers of varying thicknesses. The formation and reservoir fluid properties such as bubble point, oil saturation, water saturation, reservoir pressure were obtained from data presented by Mohammad-Singh et al. (2004) which is shown in Tables 1 and 3.

Table 1 EOR 26 upper forest sands reservoir rock properties

\begin{tabular}{ll}
\hline Rock properties & \\
\hline Area (acres) & 21 \\
Pay zone & Upper forest \\
Depth (ft) & 2600 \\
Thickness (ft) & 58 \\
Porosity (\%) & 30 \\
Permeability (md) & 150 \\
Oil saturation (\%) & 70 \\
Temperature $\left({ }^{\circ} \mathrm{F}\right)$ & 120 \\
Transmissibility (md-ft/cp) & 189 \\
\hline
\end{tabular}


Table 2 Selection criteria guide for polymer flooding. (Saleh et. al., 2014)

\begin{tabular}{|c|c|c|c|c|c|c|c|c|}
\hline Statistic & Oil gravity API & Oil viscosity, $\mathrm{cp}$ & Porosity, \% & $\begin{array}{l}\text { Oil satura- } \\
\text { tion, start }\end{array}$ & $\begin{array}{l}\text { Oil } \\
\text { saturation, } \\
\text { end }\end{array}$ & $\begin{array}{l}\text { Average } \\
\text { permeabiliaty, } \\
\text { md }\end{array}$ & Depth, $\mathrm{ft}$ & Tempertature, ${ }^{\circ} \mathrm{C}$ \\
\hline Mean & 31.2 & 12.21 & 18.15 & 55.85 & 46.57 & 384.88 & $4,004.21$ & 118.1 \\
\hline Median & 32.00 & 4.00 & 17.40 & 53.00 & 47.00 & 100.00 & 3,650 & 110 \\
\hline Standard deviation & 8.26 & 19.74 & 5.4 & 15.5 & 13.37 & 874.55 & $1,925.8$ & 30.06 \\
\hline Minimum & 12 & 0.3 & 4.1 & 21 & 20 & 0.6 & 550 & 65 \\
\hline Maximum & 48 & 130(special case, & 36.1 & 94 & 80.9 & 5,500 & 9,400 & 210 \\
\hline
\end{tabular}

Table 3 EOR 26 Upper Forest Sands Reservoir Fluid Properties

\begin{tabular}{ll}
\hline Fluid properties & \\
\hline Initial conditions & \\
Reservoir pressure (psi) & 1300 \\
Solution Gas Oil Ratio (scf/bbl) & 150 \\
Oil Formation Volume Factor (bbl/rbbl) & 1.07 \\
Oil Gravity ( $\left.{ }^{\circ} \mathrm{API}\right)$ & 17 \\
Oil Viscosity (cp) & 32 \\
At $\mathrm{CO}_{2}$ Flood start & \\
Reservoir Pressure (psi) & 600 \\
Solution Gas Oil Ratio (scf/bbl) & 80 \\
Oil Formation Volume Factor (bbl/rbbl) & 1.04 \\
Oil Vscosity (cp) & 46 \\
\hline
\end{tabular}

\section{The base model}

The model consists of six (6) wells: three (3) producers and three (3) injectors. The three (3) injectors were shut in for this model and the three (3) producers' flowing bottomhole pressure (BHP) were adjusted to achieve the desired primary production for the EOR 26 Upper Forest Sands reservoirs for the period 1961 to 1974.

\section{Base model with $\mathrm{CO}_{2}$ injection}

The model consists of six (6) wells: three (3) producers and three (3) injectors. The three (3) injectors were shut in until the year 1974 after which $\mathrm{CO}_{2}$ injection was started. For the period 1974 to 1996 , the three (3) producers and three (3) injectors were opened and the $\mathrm{CO}_{2}$ injection rates and the bottomhole pressures (BHP) for both the injectors and producers were adjusted to achieve the desired production based on the field history.

\section{1st working model}

There are seven (7) wells in this model. During the period 1961 to 1974, the well configuration and operation is identical to the base model. From 1974 to 1996 the well
Table 4 Design Variables and the ranges used in the different models

\begin{tabular}{llll}
\hline Design variables & Range & Unit \\
\cline { 2 - 3 } & Lowest value & Highest value & \\
\hline Salt concentration & 1000 & 10,000 & $\mathrm{ppm}$ \\
Polymer concentration & 400 & 2000 & $\mathrm{ppm}$ \\
Cross linker concentration & 100 & 500 & $\mathrm{ppm}$ \\
Period of Injection & 180 & 545 & days \\
Injection Rates & 500 & 4000 & bbls/day \\
Injection Pressure (Bottom & 500 & 4000 & $\mathrm{psi}$ \\
$\quad$ Hole Pressure) & & & \\
\hline
\end{tabular}

configuration and operation is as stated in the base model with $\mathrm{CO}_{2}$ injection. From 2020 to 2030, the well configuration is an inverted seven (7) spot pattern six (6) producers and one (1) injector. The Low Salinity Polymer Gel flood involved an initial low salinity water injection followed by the gel slug (polymer and cross linker polymer), which was followed by the drive water. The polymer and cross linker polymer concentrations used for the models were based on the information obtained from the research by Alghazal and Ertekin (2018) and Dukeran et al. 2018. The polymer and gel action within the reservoir was modelled.

The various design variables and the ranges used in the different models as well as the relevant relative permeability data are shown in Tables 4 and 5, respectively. The relative permeability data in Table 5 were generated in CMG using the Stone's three-phase model correlation. The Langmuir adsorption coefficients for XG and gravel packed sand for 1000 ppm Refined Xanthan Gum obtained from the novel experiment conducted by Ramkissoon et al. (2021) and shown in Table 6, were incorporated into the simulation protocols to produce enhanced EOR projections.

\section{Application of second chemical slug}

The second chemical slug will be injected in the fifth year of the project with the intent to further improve the overall oil recovery for the project and the field. The second chemical slug is a repeat of the first chemical slug injection 
Table 5 Relative permeability data

\begin{tabular}{lll}
\hline $\begin{array}{l}\text { Water saturation } \\
\left(\mathrm{S}_{\mathrm{w}}\right)\end{array}$ & $\begin{array}{l}\text { Relative permeability to } \\
\text { water }\left(\mathrm{K}_{\mathrm{rw}}\right)\end{array}$ & $\begin{array}{l}\text { Relative perme- } \\
\text { ability to oil } \\
\left(\mathrm{K}_{\mathrm{ro}}\right)\end{array}$ \\
\hline 0.2 & 0 & 0.8 \\
0.225 & 0.00117187 & 0.703125 \\
0.25 & 0.0046875 & 0.6125 \\
0.275 & 0.0105469 & 0.528125 \\
0.3 & 0.01875 & 0.45 \\
0.325 & 0.0292969 & 0.378125 \\
0.35 & 0.0421875 & 0.3125 \\
0.375 & 0.0574219 & 0.253125 \\
0.4 & 0.075 & 0.2 \\
0.425 & 0.0949219 & 0.153125 \\
0.45 & 0.117187 & 0.1125 \\
0.475 & 0.141797 & 0.078125 \\
0.5 & 0.16875 & 0.05 \\
0.525 & 0.198047 & 0.028125 \\
0.55 & 0.229688 & 0.0125 \\
0.575 & 0.263672 & 0.003125 \\
0.6 & 0.3 & 0 \\
\hline & &
\end{tabular}

Table 6 Langmuir isotherm parameters for 1000 ppm Refined Xanthan Gum (Ramkissoon et al. 2021)

\begin{tabular}{llll}
\hline Salinity $(\mathrm{ppm})$ & $\mathrm{a}(\mathrm{g} / \mathrm{L})$ & $\mathrm{b}(\mathrm{g} / 0.001 \mathrm{~L})$ & $\mathrm{b} / \mathrm{a}$ \\
\hline 0 & 0.739 & 0.001 & 0.002 \\
1000 & 0.943 & 0,002 & 0.002 \\
2000 & 1.281 & 0.002 & 0.001 \\
10,000 & 1.498 & 0.002 & 0.001 \\
20,000 & 2.408 & 0.004 & 0.002 \\
35,000 & 1.491 & 0.002 & 0.001 \\
40,000 & 1.127 & 0.001 & 0.001 \\
\hline
\end{tabular}

utilizing the same time period, concentrations of the different chemicals and the order in which they were injected into the reservoir.

\section{Economic model}

The economic model was developed using the possible Capital Expenditure (CAPEX) and Operating Expenditure (OPEX) for the implementation and operation of the Low Salinity Polymer Gel flood. The economic model was also designed considering the local jurisdiction royalties and taxes which were incorporated into the expenditure for the project. The economic model will consider Minimum Acceptable Rate of Return (MARR), Net Present Value (NPV), Payback period (PAYBACK) and Internal Rate of Return (IRR) as the feasibility indicators.

\section{Results and discussion}

The EOR 26 Upper Forest Sands field structure contour map obtained from previous work conducted by Mohammad-Singh et al. (2004), was digitized using the Didger software, and the map is shown in Fig. 2.

The EOR 26 Base Model simulation was constructed using CMG Builder with the digitized EOR 26 structure contour map being imported into the CMG Builder. The EOR 26 Base Model was prepared to match its primary production from 1961 to 1974 using CMG STARS and CMOST. The CMOST History Matching Results for EOR 26 Base Model is shown in Fig. 3. The CO2 Injection was added to the EOR 26 Base Model to match the field's production history from 1975 to 1996 in which Carbon Dioxide was injected into the EOR 26 Upper Forest Sands reservoirs to improve oil recovery. The EOR 26 Base Model was manually history matched using CMG Builder and CMG STARS to obtain the cumulative production attained by the actual EOR 26 Upper Forest Sands at the end of the primary production and $\mathrm{CO}_{2}$ injection phases.

The parameters inputted into CMOST to execute the history match were permeability, porosity and the bottomhole pressure for each producer well in the model. There were three (3) objective functions used in CMOST, they were the cumulative oil produced, the cumulative gas produced and the cumulative water produced. The focus was placed on the cumulative oil produced objective function for the purpose of this study.

The results of the simulation exercise is shown in Table 7 and clearly show that simulation models with higher gel concentrations and lower polymer concentration attained higher percentage oil recoveries inferring that the gel is more effective and efficient at sweeping the reservoir than the polymer. The Gel concentration of $500 \mathrm{ppm}$ with no polymer resulted in the highest Total Oil Recovery $(\sim 26 \%)$.

The optimum injection rate and injection pressure that can be utilized to achieve the highest possible oil recovery without exceeding the formation fracture pressure was investigated. The formation fracture pressure for the EOR 26 was calculated using Eq. 1 below and it was found to be 2205 psi.

Fracture pressure $=0.7 \mathrm{psi} / \mathrm{ft} \times$ depth of reservoir $(\mathrm{ft})$

Table 8 shows the results of the field simulation optimization exercise and shows the effect of days of injection and injection rate and pressure on total oil recovery (\%) for EOR 26. The initial reservoir pressure was1300 psi.

The results highlight that there were no significant increases in the oil recovery levels at higher injection rates and higher injection pressures even after the fracture pressure was exceeded. 


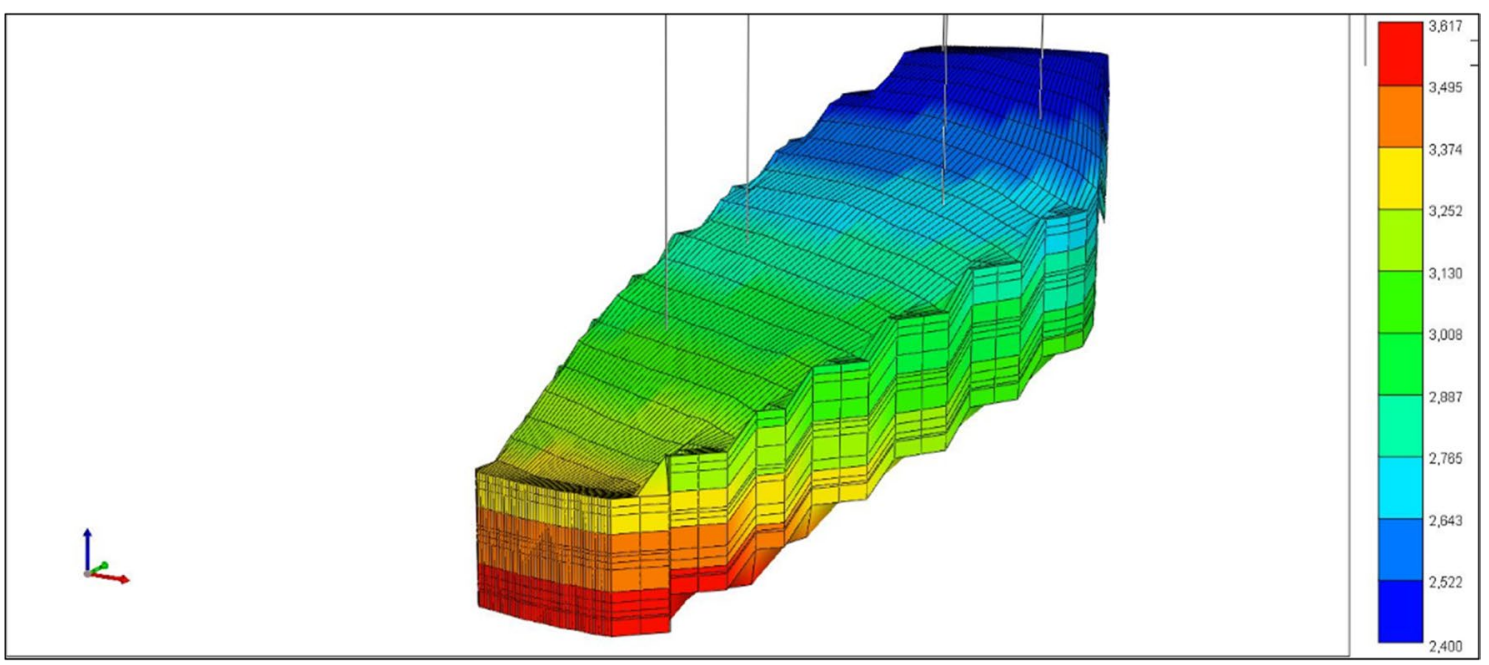

Fig. 2 Digital Contour Map of EOR 26

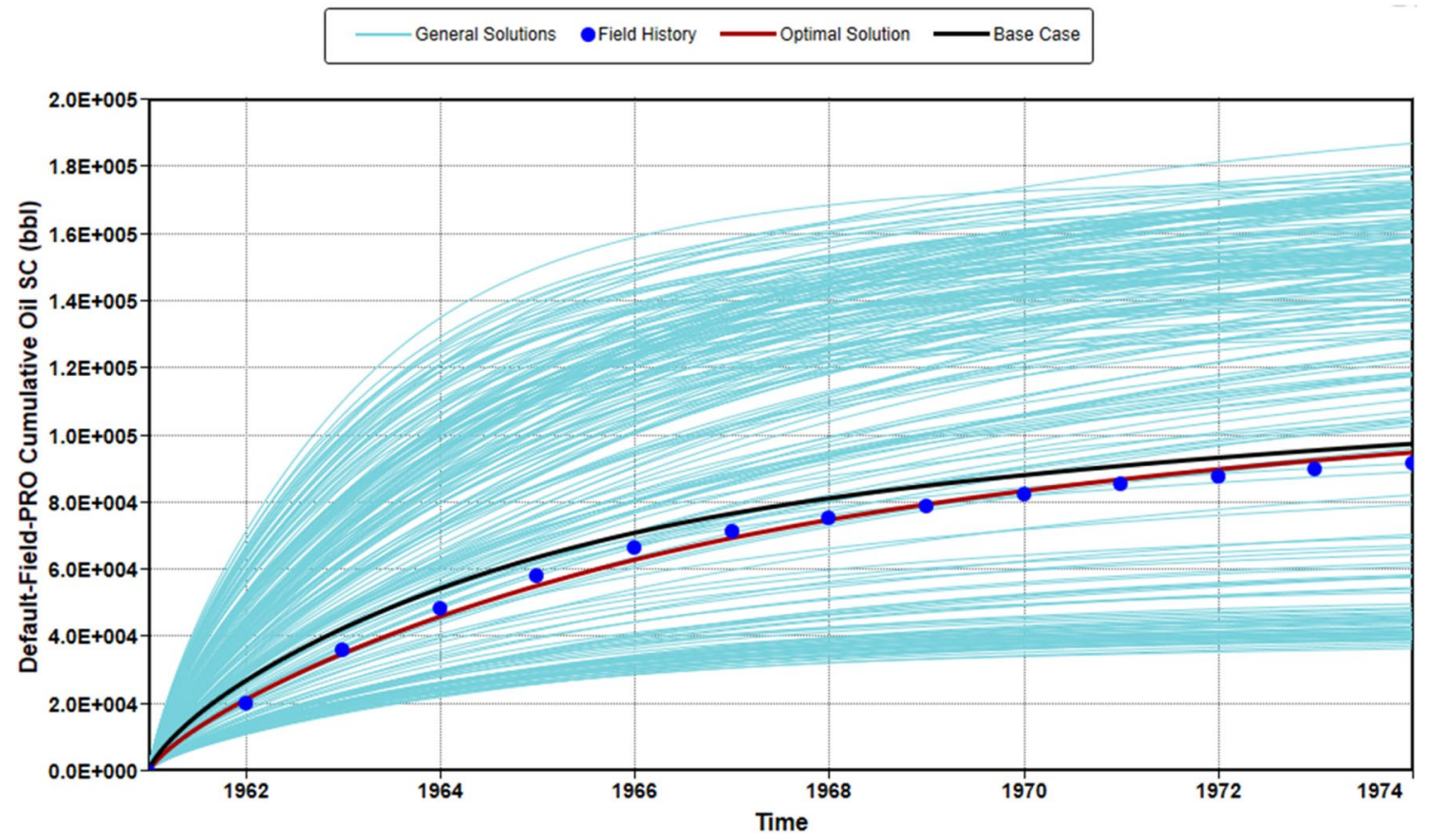

Fig. 3 CMOST History Matching Results for EOR 26 Base Model from 1961 to 1974

With respect to Cumulative Oil recovered, Fig. 4 shows the effect of the injection rates on this parameter. It was observed that as the injection rates increase the Cumulative Oil recovered generally increase.

Figure 5 shows the effect of the injection rate on the average reservoir pressure within the reservoir. The results demonstrate that as the injection rate increases the average reservoir pressure also increases and as highlighted in Fig. 5 at the injection rates of 1100 bbls/day and 1300 bbls/ day the average reservoir pressure exceeded the formation fracture pressure. A key consideration of this strategy is that the increase in the injection rate must not cause an increase in the pressure within the reservoir beyond the formation fracture pressure.

The results of the simulation optimizations with respect to the effect of salinity on EOR 26 field's Total Oil Recovery (\%) are shown in Table 9.

The results indicate that as the salinity concentration was increased from 1000 to $10000 \mathrm{ppm}$, there was a marginal decrease in the Total Oil Recovery (\%). When the data from 
Table 7 Effect of Polymer Gel concentration on EOR 26 field simulation optimization

\begin{tabular}{lll}
\hline $\begin{array}{l}\text { Polymer concentration } \\
(\mathrm{ppm})\end{array}$ & Gel concentration (ppm) & $\begin{array}{l}\text { Total oil } \\
\text { recovery } \\
(\%)\end{array}$ \\
\hline 1500 & 0 & 22.23 \\
0 & 500 & 25.92 \\
1000 & 100 & 22.30 \\
500 & 100 & 23.55 \\
1500 & 200 & 22.61 \\
400 & 100 & 23.50 \\
2000 & 100 & 22.44 \\
\hline
\end{tabular}

Table 8 Effect of Injection Rate and Pressure on EOR 26 field simulation optimization

\begin{tabular}{lllll}
\hline $\begin{array}{l}\text { Days of } \\
\text { injec- } \\
\text { tion }\end{array}$ & $\begin{array}{l}\text { Injec- } \\
\text { tion rate } \\
\text { (bbls) }\end{array}$ & $\begin{array}{l}\text { Injection } \\
\text { pressure BHP } \\
\text { (psi) }\end{array}$ & $\begin{array}{l}\text { Hydrocarbon } \\
\text { pore volume } \\
\text { (HCPV) }\end{array}$ & $\begin{array}{l}\text { Total oil } \\
\text { recovery } \\
(\%)\end{array}$ \\
\hline 545 & 1000 & 1000 & 0.3 & 21.61 \\
545 & 1500 & 1500 & 0.45 & 23.28 \\
180 & 2000 & 2000 & 0.2 & 23.09 \\
180 & 4000 & 4000 & 0.4 & 23.55 \\
\hline
\end{tabular}

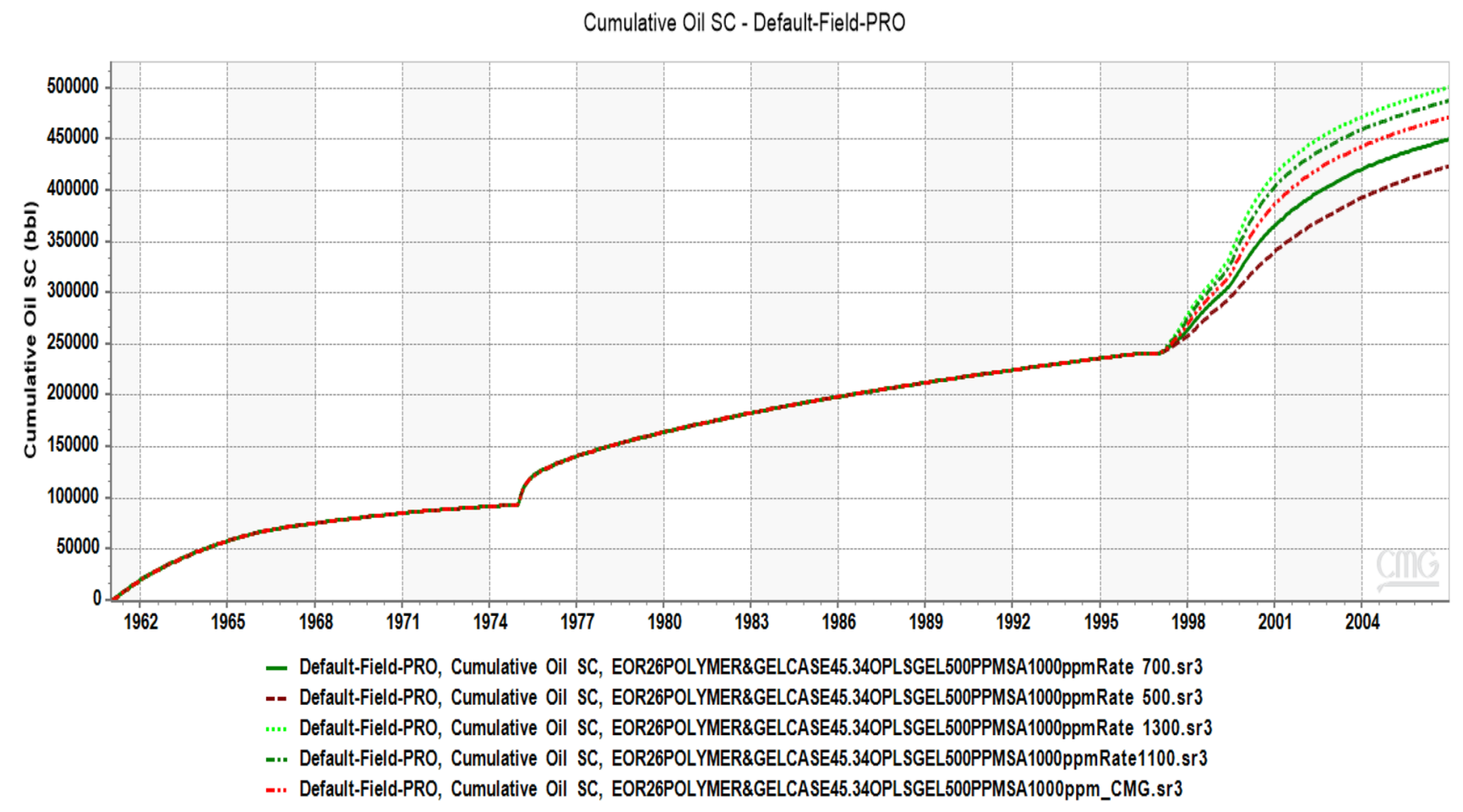

Fig. 4 Effect of the injection rate on the Cumulative Oil recovered
Table 9 is compared to the performance of the waterflooding strategy shown in Table 11 (which outlined a comparison of the performance parameters of the different models), the effect of the salinity results in an associated two (2) percent increase in the Total Oil Recovery (\%). This can attributed to low salinity concentration of the water as opposed to the waterflood using fresh water, which is consistent with previous research conducted by Mahani et al., (2015) who demonstrated that the main effect of low salinity water injection is to improve wettability characteristic within the reservoir as opposed to areal sweep efficiency. The low salinity water injection made the reservoir within the model more water wet, as the reservoir's wettability improved more oil molecules became available to be swept which resulted in a higher percentage oil recovery being observed.

The results of the comparison of key parameters for the first working model of the Low Salinity Polymer Gel flood simulation model and the Optimized Low Salinity Polymer Gel flood simulation model are shown in Table 10.

The results demonstrate that the Optimized Low Salinity Polymer Gel flood model utilizes a higher salinity concentration and a lower concentration of polymer gel to achieve a higher Percentage Oil Recovery Factor (\%) (approximately $25 \%$ higher) compared to the un-optimized model. The low salinity polymer gel chemical slug was also injected for a longer period than the chemical slug injection period for the first working model. The results suggest that in the

Fig.4 Effect of the injection rate on the Cumulative Oil recovered 


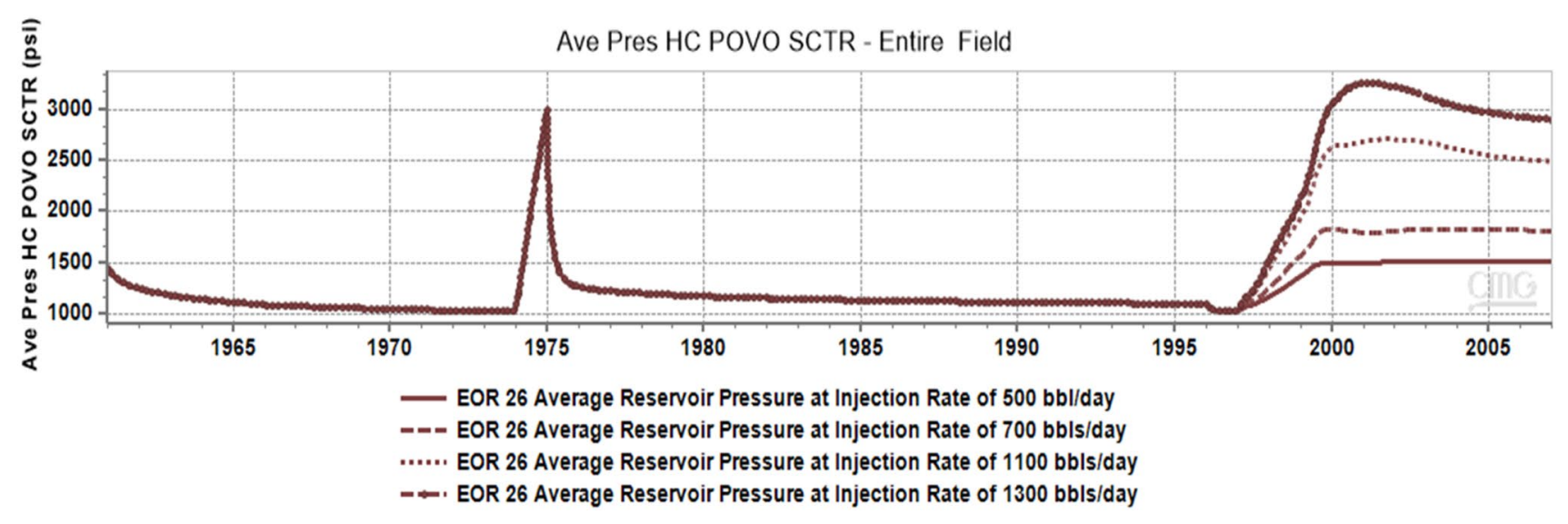

Fig. 5 Effect of the injection rate on the average reservoir pressure

Table 9 Effect of Salinity on EOR 26 field simulation optimization

\begin{tabular}{ll}
\hline $\begin{array}{l}\text { Salinity concen- } \\
\text { tration }(\mathrm{ppm})\end{array}$ & $\begin{array}{l}\text { Total oil } \\
\text { recovery } \\
(\%)\end{array}$ \\
\hline 1000 & 23.28 \\
2000 & 23.28 \\
4000 & 23.23 \\
10,000 & 23.13 \\
\hline
\end{tabular}

Table 10 Comparison of the Low Salinity Polymer Gel and the Optimized Low Salinity Polymer Gel flood models

\begin{tabular}{lll}
\hline $\begin{array}{l}\text { CMG simulation model } \\
\text { Parameter }\end{array}$ & $\begin{array}{l}\text { Low salinity } \\
\text { polymer gel } \\
\text { flood }\end{array}$ & $\begin{array}{l}\text { Optimized low } \\
\text { salinity polymer gel } \\
\text { flood }\end{array}$ \\
\hline Water mole fraction & 0.999995800 & 0.999689613 \\
$\begin{array}{l}\text { Polymer mole fraction } \\
\text { NaCl mole fraction }\end{array}$ & $\begin{array}{l}2.00 \mathrm{E}-06 \\
2.00 \mathrm{E}-06\end{array}$ & $\begin{array}{l}1.13 \mathrm{E}-06 \\
\text { Xlinker mole fraction }\end{array}$ \\
$\begin{array}{l}\text { Polymer Gel Slug period, } \\
\text { days }\end{array}$ & 36000308162 \\
$\begin{array}{l}\text { Cumulative oil production, } \\
\text { bbls }\end{array}$ & 376,387 & $1.10 \mathrm{E}+06$ \\
$\begin{array}{l}\text { Percentage oil recovery factor } \\
(\%)\end{array}$ & 21.64 & 545 \\
\hline
\end{tabular}

optimized Low Salinity Polymer Gel flood, the gel, which is generated in situ, improves the macroscopic and microscopic displacement efficiency of the displacing fluid thus enabling it to be more effective at sweeping the reservoir. Polymer gel systems can mitigate the reduction of sweep efficiency due to the presence of high-permeability features including fissures, fractures, and eroded out zones. Implementing crosslinked polymer gels in injection and/or production wells can improve flow-driving properties and lead to increasing the recovery factor of enhanced oil recovery/improved oil recovery (EOR/IOR) treatments.

A combination of Low Salinity Polymer and Low Salinity Gel flooding was added to the Base Model with $\mathrm{CO}_{2}$ Injection for a period of 10 years to further improve the total oil recovery for the EOR 26 Upper Forest Sands field and the results are shown in Table 11.

There was a period of pre flush water injection for 180 days followed by the aqueous solution of Low Salinity Polymer Gel chemical slug injection for a period of 365 days. The chemical slug of low salinity polymer gel was followed by a water injection for the remainder of the flooding period to push the chemical slug through the formation. The formation of the gel in situ was verified by the presence of a small quantity of gel along with the polymer at one of the producers.

The values for the cumulative oil production, oil recovery and average oil saturation after the flood show that the optimized low salinity polymer gel flood was the most effective method for reducing the average oil saturation and the low salinity water flood and conventional waterflood were the least effective. The results are very interesting as it highlighted the observation that that there was not a significant difference between the effectiveness of the water flood and the low salinity water flood strategies. In the argument for optimization, it was proffered that the low salinity will be used essentially for changing the rock wettability from more oil wet to more water wet, which is in favour of increased oil recovery. It can be inferred from the results that the low salinity water flood sweep efficiency would have been less than that of the polymer flood. The results also suggest that the combined optimized low salinity polymer gel flood was most effective at reducing the average oil saturation because it combined the benefit of low salinity (allowing more oil molecules available to be swept) and the improved sweeping 
Table 11 Comparison of Performance Parameters from Different Models

\begin{tabular}{llllll}
\hline $\begin{array}{l}\text { CMG Simulation Model } \\
\text { Parameter }\end{array}$ & Waterflood & $\begin{array}{l}\text { Low Salinity } \\
\text { Waterflood }\end{array}$ & Polymer Flood & $\begin{array}{l}\text { Low Salinity Poly- } \\
\text { mer Gel Flood }\end{array}$ & $\begin{array}{l}\text { Optimized Low } \\
\text { Salinity Polymer Gel } \\
\text { Flood }\end{array}$ \\
\hline Cum. Water Injected, bbls & $1.44 \mathrm{E}+07$ & $5.44 \mathrm{E}+06$ & $3.27 \mathrm{E}+06$ & $3.27 \mathrm{E}+06$ & $3.27 \mathrm{E}+06$ \\
Average Reservoir Pressure, psi & 1390 & 1345.42 & 1928 & 1634 & 2074 \\
Oil Saturation after flood & 0.464 & 0.453 & 0.434 & 0.451 & 0.422 \\
Cumulative Oil Production, bbls & 341,705 & 372,104 & 417,858 & 376,387 & 471,001 \\
Percentage Oil Recovery Factor, $\%$ & 20.92 & 21.36 & 24.02 & 21.64 & 27.04 \\
\hline
\end{tabular}

Table 12 The key Assumptions use in the Economic Model

\begin{tabular}{lll}
\hline Variable & Unit & Amount \\
\hline PRICE & US\$/bbl & 50 \\
OPEX & US\$/bbl & 18 \\
CAPEX & US\$MM & $\$ 220,638.00$ \\
Royalty Rate & $\%$ & 10.00 \\
SPT & $\%$ & 25.00 \\
GFL & $\%$ & 0.30 \\
PPL & $\%$ & 4.00 \\
UL & $\%$ & 5.00 \\
PPT & $\%$ & 50.00 \\
MARR & $\%$ & 10.00 \\
\hline
\end{tabular}

efficiency of the polymer gel flood. This improvement is reflected in the observed higher percentage oil recovery from the optimized low salinity polymer gel flood when compared to the conventional water flood, the low salinity water flood and the polymer gel flood.

\section{Economic modelling}

The field simulation model of the low salinity polymer gel flood is functional and its performance was optimized to improve oil recovery. The optimized field simulation model was analysed in terms of economics and as the resulting economic model will provide the financial information to inform the decision-making with respect to the implementation of the strategy. The economic model looks at the capital expenditure required to implement the optimized low salinity polymer gel flood, its risk profile and the royalties and taxes due to the Government of TT based on oil production from the EOR 26 Upper Forest Sands field. The parameters utilized and the key assumptions associated relevant to the jurisdiction of the Republic of TT are listed below and in Table 12, respectively, and were used as inputs for the economic model.

- $\mathrm{Gel}=500 \mathrm{ppm}$ Polymer +500 ppm Cross Xlinker
Table 13 Probable Gross Income generated over a 10-year period at a minimum crude oil price of $\$ 50$ USD per barrel

\begin{tabular}{lll}
\hline Year & $\begin{array}{l}\text { Production } \\
\text { Bbl }\end{array}$ & $\begin{array}{l}\text { Gross Income } \\
\text { US\$ }\end{array}$ \\
\hline 2020 & 18,000 & $\$ 900,000$ \\
2021 & 38,000 & $\$ 1,900,000$ \\
2022 & 44,350 & $\$ 2,217,500$ \\
2023 & 37,890 & $\$ 1,894,500$ \\
2024 & 22,360 & $\$ 1,118,000$ \\
2025 & 15,000 & $\$ 750,000$ \\
2026 & 12,500 & $\$ 625,000$ \\
2027 & 8,577 & $\$ 428,850$ \\
2028 & 7,117 & $\$ 355,850$ \\
2029 & 6,525 & $\$ 326,250$ \\
2030 & 6,205 & $\$ 310,250$ \\
\hline
\end{tabular}

- Liquid Injection Rate $=900$ bbls/day

- Polymer + Cross Xlinker injected $=0.001 \times 900 \mathrm{bbls} /$ day $=0.9$ bbls/day

- Polymer Cost $=$ US $\$ 0.78 / \mathrm{bbl}$

- Gel slug cost $=$ US\$0.78 / bbl $\times 0.9$ bbls/ day $\times 545$ days $=$ US $\$ 382.60$

- $\mathrm{CAPEX}=$ Water injection installation + Polymer injection installation cost + Gel slug cost

- $\mathrm{CAPEX}=\mathrm{US} \$ 110,000+\mathrm{US} \$ 110,000+\mathrm{US} \$$ $637.65=$ US\$ 220,383

- $\mathrm{OPEX}_{\mathrm{POLYMER}}=$ Polymer injection cost $=\mathrm{US} \$ 0.28 / \mathrm{bbl}$

- $\mathrm{OPEX}_{\mathrm{WATER}}=$ Water injection cost $=\mathrm{US} \$ 17 / \mathrm{bbl}$

Results derived from the model pertaining to the probable gross income generated over a 10 -year period at a minimum crude oil price of \$50 USD per barrel are shown in Table 13.

From the data presented in Table 13, it can be seen that a maximum production of $44,350 \mathrm{bbl}$ of crude oil, reflecting a gross income of $\$ 2,217,500$ USD was obtained in the year 2022. After increasing significantly from 2020 to the maximum gross income value in 2022 , the values steadily decreased to approximately $14 \%$ of the maximum value by 2030 . 
I terms of the probable taxes payable, the data presented on Table 14 shows the probable taxes based on gross income which for the jurisdiction of the Republic of TT.

As expected, the total taxes due correlates directly with the gross income values as the total taxes due yearly represents (3) fixed applicable taxes applied to the Gross Income of an energy company operating in the oil and gas sector. These taxes are the Supplementary Petroleum Tax (SPT), the Green Fund Levy (GFL) and the Petroleum Production Levy (PPL); the respective percentages previously listed in Table 12.
Table 14 Probable taxes in USD based on gross income

\begin{tabular}{lcrllll}
\hline Year & Gross Income & Royalty & $\begin{array}{l}\text { Supplementary } \\
\text { Petroleum Tax }\end{array}$ & Green Levy Fund & $\begin{array}{l}\text { Petroleum Pro- } \\
\text { duction Levy }\end{array}$ & Total Taxes \\
\hline 2020 & 900,000 & 90,000 & 202,500 & $\$ 2,700$ & 36,000 & 331,200 \\
2021 & $1,900,000$ & 190,000 & 427,500 & $\$ 5,700$ & 76,000 & 699,200 \\
2022 & $2,217,500$ & 221,750 & 498,937 & $\$ 6,652$ & 88,700 & 816,040 \\
2023 & $1,894,500$ & 189,450 & 426,262 & $\$ 5,683$ & 75,780 & 697,176 \\
2024 & $1,118,000$ & 111,800 & 251,550 & $\$ 3,354$ & 44,720 & 411,424 \\
2025 & 750,000 & 75,000 & 168,750 & $\$ 2,250$ & 30,000 & 276,000 \\
2026 & 625,000 & 62,500 & 140,625 & $\$ 1,875$ & 25,000 & 230,000 \\
2027 & 428,850 & 42,885 & 96,491 & $\$ 1,286$ & 17,154 & 157,816 \\
2028 & 355,850 & 35,585 & 80,066 & $\$ 1,067$ & 14,234 & 130,952 \\
2029 & 326,250 & 32,625 & 73,406 & $\$ 978$ & 13,050 & 120,060 \\
2030 & 310,250 & 31,025 & 69,806 & $\$ 930$ & 12,410 & 114,172 \\
\hline
\end{tabular}

Table 15 Chargeable income in USD based on gross income

\begin{tabular}{lccclccc}
\hline Year & Gross income & OPEX & Capital allowance & $\begin{array}{l}\text { Taxes based on } \\
\text { gross income }\end{array}$ & Profit/Loss & $\begin{array}{l}\text { Cumulative } \\
\text { loss }\end{array}$ & Chargeable income \\
\hline 2020 & 900,000 & 324,000 & 110,319 & 331,200 & 134,481 & 0 & 134,481 \\
2021 & $1,900,000$ & 684,000 & 66,191 & 699,200 & 450,608 & 0 & 450,608 \\
2022 & $2,217,500$ & 798,300 & 44,127 & 816,040 & 559,032 & 0 & 559,032 \\
2023 & $1,894,500$ & 682,020 & & 697,176 & 515,304 & 0 & 515,304 \\
2024 & $1,118,000$ & 402,480 & & 411,424 & 304,096 & 0 & 304,096 \\
2025 & 750,000 & 270,000 & & 276,000 & 204,000 & 0 & 204,000 \\
2026 & 625,000 & 225,000 & & 230,000 & 170,000 & 0 & 170,000 \\
2027 & 428,850 & 154,386 & & 157,816 & 116,647 & 0 & 116,647 \\
2028 & 355,850 & 128,106 & & 130,952 & 96,791 & 0 & 96,791 \\
2029 & 326,250 & 117,450 & & 120,060 & 88,740 & 0 & 88,740 \\
2030 & 310,250 & 111,690 & & 114,172 & 84,388 & 0 & 84,388
\end{tabular}

Table 16 Taxes based on Chargeable income in USD

\begin{tabular}{lcccc}
\hline Year & Chargeable income & $\begin{array}{c}\text { Unemployment } \\
\text { levy tax }\end{array}$ & Petroleum profit tax & $\begin{array}{c}\text { Total taxes based on } \\
\text { chargeable income }\end{array}$ \\
\hline 2020 & 134,481 & 6,724 & 67,240 & 73,964 \\
2021 & 450,608 & 22,530 & 225,304 & 247,834 \\
2022 & 559,032 & 27,951 & 279,516 & 307,467 \\
2023 & 515,304 & 25,765 & 257,652 & 283,417 \\
2024 & 304,096 & 15,204 & 152,048 & 167,252 \\
2025 & 204,000 & 10,200 & 102,000 & 112,200 \\
2026 & 170,000 & 8,500 & 85,000 & 93,500 \\
2027 & 116,647 & 5,832 & 58,323 & 64,155 \\
2028 & 96,791 & 4,839 & 48,395 & 53,235 \\
2029 & 88,740 & 4,437 & 44,370 & 48,807 \\
2030 & 84,388 & 4,219 & 42,194 & 46,413 \\
\hline
\end{tabular}


The Chargeable Income is the monies available to be taxed after the Operating Expenses, Capital Allowance and Taxes Based on Gross Income are deducted from the Gross Income. As far as the Chargeable income is concerned, the data calculated are presented in Table 15.

In the Republic of TT there are two (2) taxes applied to the Chargeable Income of an energy company operating in the oil and gas sector, and they include the Unemployment Levy (UL) and the Petroleum Profit Tax (PPT); the respective percentage of each tax previously listed in Table 12. The Taxes Based on Chargeable Income for this study over the 10-year period are shown in Table 16.

The calculated results for the Net Cash Flow derived from the economic model is presented in Table 17.

The Net Cash flow provides a summary of the cash flow projection over the ten (10) year period for the project from implementation of the project to operations. The cash flow projection takes into consideration the effect of CAPEX, OPEX, Taxes Based on Gross Income and Taxes Based on Chargeable Income. Due to the applicable CAPEX in 2020, the Net Cash Flow as well as the Discounted Net Cash Flow were negative for that year but was positive for the following nine years peaking in 2022. In terms of NPV, results indicate that over the 10-year period, utilizing a MARR of $30 \%$, a NPV of $\$ 326,847.19$ USD and an IRR of $63.53 \%$ were estimated for this well. The NPV was positive from year 2 of the optimized strategy.

Sensitivity analysis for the variation of the NPV and IRR with the price per barrel of crude oil was conducted and the results shown in Figs. 6 and 7, respectively.

The NPV and IRR values increased with the price of oil with the break-even oil price for the implementation and operation of the optimized Low Salinity Polymer Gel flooding project being observed at US $\$ 31$ per barrel of oil (Fig. 7).

\section{Conclusion}

A field simulation model of a combined Low Salinity Polymer Gel flood using the EOR 26 Upper Forest Sands to improve oil recovery was developed. The optimized EOR 26 Upper Forest Sands field simulation model of a Salinity Polymer Gel flood was attained at a polymer gel concentration of $500 \mathrm{ppm}$, salinity concentration of $1000 \mathrm{ppm}$ and an injection rate and pressure of $900 \mathrm{bbl} / \mathrm{day}$ and $900 \mathrm{psi}$ BHP, respectively. The injection was via a chemical slug for a continuous period of 545 days preceded by pre flush water injection for 180 days and post-chemical slug drive water injection for the duration of the ten (10) year period. Economic analysis demonstrated that the Optimized Low Salinity Polymer Gel flood project implementation and

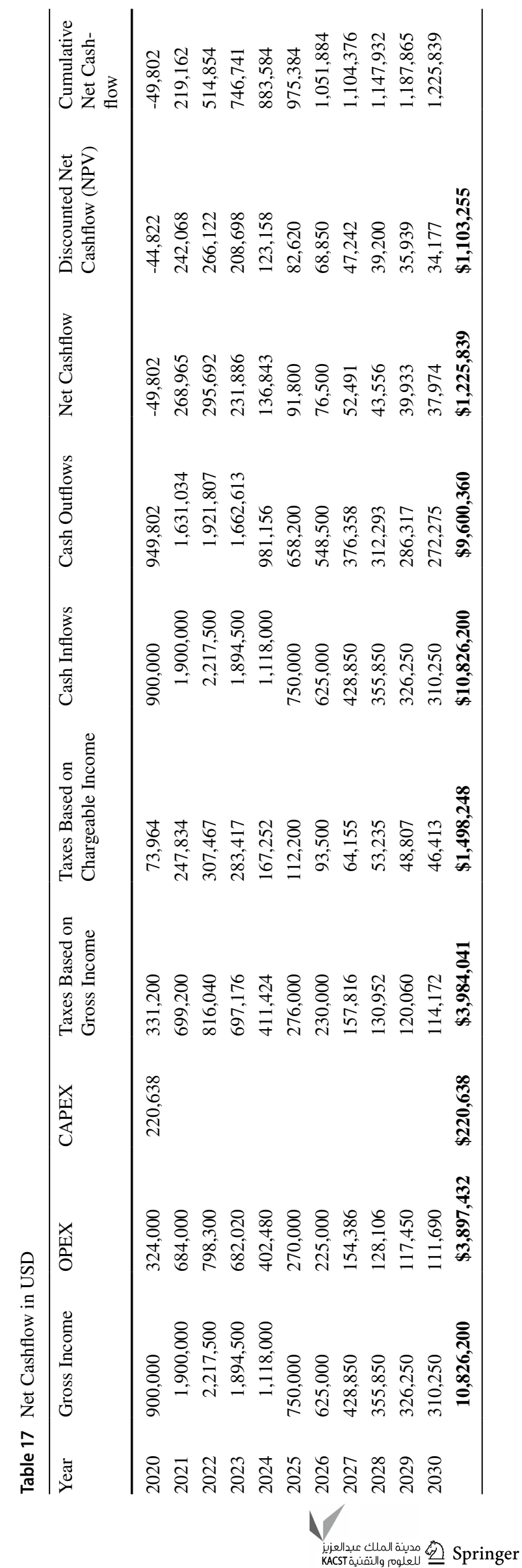


Fig. 6 Relationship between NPV and Crude Oil Prices

Fig. 7 Relationship between IRR and Crude Oil Prices
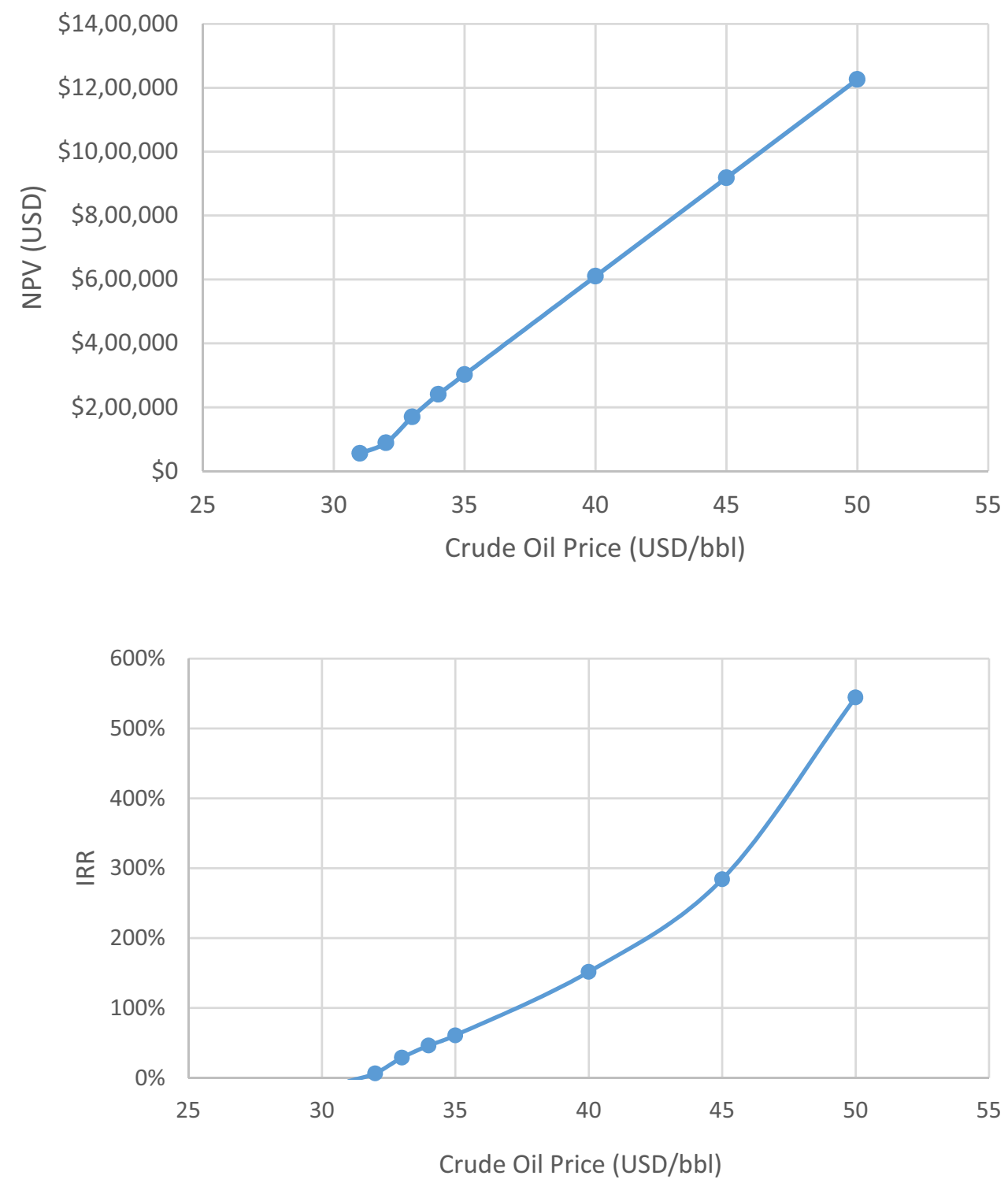

operation can be economically feasible using a crude oil price of US\$50 per barrel with a capital injection of approximately US\$221,000 and an associated pays back period of the initial capital investment within two (2) years. The internal rate of return over the ten (10) year duration of the project is 63.53 percent.

Funding The authors of this manuscript received no funding for the work reported in their manuscript.

\section{Declarations}

Conflict of interest On behalf of all the co-authors, the corresponding author states that there is no conflict of interest.
Human or animal participants The research was conducted with Compliance with Ethical Standards and did not involve Human Participants and/or Animals.

Open Access This article is licensed under a Creative Commons Attribution 4.0 International License, which permits use, sharing, adaptation, distribution and reproduction in any medium or format, as long as you give appropriate credit to the original author(s) and the source, provide a link to the Creative Commons licence, and indicate if changes were made. The images or other third party material in this article are included in the article's Creative Commons licence, unless indicated otherwise in a credit line to the material. If material is not included in the article's Creative Commons licence and your intended use is not permitted by statutory regulation or exceeds the permitted use, you will need to obtain permission directly from the copyright holder. To view a copy of this licence, visit http://creativecommons.org/licenses/by/4.0/. 


\section{References}

Al-Anazi HA, Sharma MM (2002) Use of a pH sensitive polymer for conformance control. Soc Pet Eng. https://doi.org/10.2118/ 73782-MS

Al-Shakry B, Shiran BS, Skauge T, and Skauge A (2018) Enhanced oil recovery by polymer flooding: optimizing polymer injectivity. In: Paper presented at the SPE Kingdom of Saudi Arabia Annual Technical Symposium and Exhibition, Dammam, Saudi Arabia, April 2018. https://doi.org/10.2118/192437-MS

Alghazal M, and Ertekin T (2018) Assisted design of polymer-gel floods in naturally fractured reservoirs using neuro-simulation based models. In: Paper presented at the Abu Dhabi International Petroleum Exhibition \& Conference, Abu Dhabi, UAE, November 2018. https://doi-org.research.library.u.tt/https://doi.org/10.2118/ 192602-MS

De Simoni M, Boccuni F, Sambiase M, Spagnuolo M, Albertini M, Tiani A, Masserano F (2018) Polymer injectivity analysis and subsurface polymer behavior evaluation. Soc Pet Eng. https://doi. org/10.2118/190383-MS

Delamaide E, Bazin B, Rousseau D, and Degre G (2014) Chemical EOR for heavy oil: the canadian experience. In: Paper presented at the SPE EOR Conference at Oil and Gas West Asia, Muscat, Oman, March 2014. https://doi-org.research.library.u.tt/https:// doi.org/10.2118/169715-MS

Dukeran R, Soroush M, Alexander D, Shahkarami A, Boodlal D (2018) Polymer flooding application in trinidad heavy oil reservoirs. Soc Pet Eng. https://doi.org/10.2118/191204-MS

Fortenberry R, Kim DH, Nizamidin N, Adkins S, Arachchilage GP, Koh HS, Pope GA (2015) Use of cosolvents to improve alkaline/polymer flooding. Soc Pet Eng. https://doi.org/10.2118/ 166478-PA

Lager A, Webb KJ, Black CJJ, Singleton M, Sorbie KS (2008) Low salinity oil recovery-An experimental investigation. Petrophysics 49(1):28-35

Luo JH, Liu YZ, Zhu P (2006) Polymer solution properties and displacement mechanisms. In: Shen PP, Liu YZ, Liu HR (eds) Enhanced oil recovery-polymer flooding. Petroleum Industry Press, Beijing, pp 1-72

Mahini H, Berg S, Ilic D, Bartels W-B-B, and Joekar-Niasar V (2015) Kinetics of Low-Salinity-Flooding Effect. SPE J 20: 8-20. https:// doi-org.research.library.u.tt/https://doi.org/10.2118/165255-PA

Ministry of Energy and Energy Industries (2019) Retrieved on 21 January 2021 from Historical Facts on the Petroleum Industry of Trinidad and Tobago: http://www.energy.gov.tt/historical-factspetroleum/

Mohammad-Singh L, Singhal J, Ashok K (2004) Lessons from Trinidad's CO2 immiscible pilot projects 1973-2003. Retrieved on 21 January 2021 from https://www-onepetro-org.research.library.u. tt/download/conference-paper/SPE-89364-MS?id=conferencepaper\%2FSPE-89364-MS
Morrow N, Buckley J (2011) Improved oil recovery by low-salinity waterflooding. J Pet Technol 63:106-112. https://doi.org/10.2118/ 129421-JPT

Needham RB, and Doe PH (1987) Polymer Flooding Review. J Pet Technol 39: 1503-1507. https://doi-org.research. library.u.tt/https://doi.org/10.2118/17140-PA

Ramkissoon S, Maharaj R, Alexander D et al (2021) Selection of an EOR technique for the matured EOR 33 reservoir in Southern Trinidad using adsorption and simulation studies. Arab J Geosci 14:2548. https://doi.org/10.1007/s12517-021-08852-z

Saleh LD, Wei M, Bai B (2014) Data analysis and updated screening criteria for polymer flooding based on oilfield data. Soc Pet Eng. https://doi.org/10.2118/168220-PA

Sheng JJ (2013) A comprehensive review of alkaline-surfactant-polymer (ASP) flooding. In: Paper presented at the SPE Western Regional \& AAPG Pacific Section Meeting Joint Technical Conference, Monterey, California, USA, April 2013. https://doi-org. research.library.u.tt/https://doi.org/10.2118/165358-MS

Sheng JJ (2015) Status of polymer-flooding technology. https://wwwonepetro-org.research.library.u.tt/download/journal-paper/SPE174541-PA?id=journal-paper\%2FSPE-174541-PA

Sinanan B, Evans D, Budri M (2016) SPE 180853-MS: conceptualizing an improved oil recovery master plan for Trinidad \& Tobago. SPE J. https://doi.org/10.2118/180853-MS

Taber JJ, Martin FD, Seright RS (1997) EOR screening criteria revisited part 1: introduction to screening criteria and enhanced recovery field projects. in spe reservoir engineering. https://www-onepe tro-org.research.library.u.tt/download/journal-paper/SPE-35385PA?id=journal-paper\%2FSPE-35385-PA

Thomas S (2006) Chemical EOR: The Past - Does It Have a Future? Paper SPE 108828 Based on a speech presented as a Distinguished Lecture.

Wang D, Dong H, Lv C, Fu X, Nie J (2009) Review of practical experience by polymer flooding at daqing. SPE Res Eval Eng 12:470 476. https://doi.org/10.2118/114342-PA

Worldometer. (n.d.). Current world population. Retrieved January 16, 2021, from https://www.worldometers.info/

Xia HF, Wang DM, Wang G, Ma WG, Liu J (2008) Mechanism of the effect of micro-forces on residual oil in chemical flooding. In: SPE 115315 presented at SPE/DOE improved oil recovery symposium, Oklahoma, 19-23 April 2008

Yin HJ, Wang DM, Zhang H (2006) Study on flow behaviors of viscoelastic polymer solution in micropore with dead end. In: SPE 101950 presented at SPE annual technical conference and exhibition, Texas, 24-27 Sept 2006

Publisher's Note Springer Nature remains neutral with regard to jurisdictional claims in published maps and institutional affiliations. 